\title{
The Effect Of Asset Structure, Capital Structure, Macro Economy And Financial Risk Management On The Value of The Firm In Companies Listed On The Jakarta Islamic Index
}

\author{
Solichah \\ Fakultas Ekonomi dan Bisnis, \\ Universitas 17 Agustus 1945, Jawa Timur, Indonesia \\ Tri Ratnawati \\ Fakultas Ekonomi dan Bisnis, \\ Universitas 17 Agustus 1945, Jawa Timur, Indonesia \\ Srie Hartutuie Moehaditoyo \\ Fakultas Ekonomi dan Bisnis, \\ Universitas 17 Agustus 1945, Jawa Timur, Indonesia
}

\begin{abstract}
The Islamic capital market has importtant roles, they are as a source of funding for companies for business development through the issuance of syari'ah securities, as a means of syari'ah securities for syari'ah capital market investors that are universal, can be utilized by anyone regardless of ethnic, religion and racial backgrounds. The purpose of this research to 1) examine, analyze and prove the Asset Structure, Capital Structure, Macroeconomics of Financial Risk Management, 2) examine, analyze and prove the Asset Structure, Capital Structure, Macroeconomics of the Value of the Firm, 3) examine, analyze and prove Financial Risk Management to the Value of the Firm. The population and sample in this study were 16 syri'ah stock companies listed on the Jakarta Islamic Index, from 2013 to 2017, with keriteria and saturated sampling techniques. This type of research is quantitative research secondary data research data obtained by IDX (Indonesia stock exchange) webset. Data examining techniques using PLS test equipment. The results show that the t-statistic: means: asset structure had no significant effect on financial risk management: means: asset structure had a significant effect on the value of the firm: means: capital structure has a significant effect on financial risk management: means: capital structure has no significant effect on the value of the firm: means: macro economic has a significant effect on financial risk management: giving the meaning of macro economic significantly influencing the value of the firm: giving the meaning of financial risk management having a significant effect on the value of the firm. Conclusions of the study 1) Asset structure has no effect and no significant effect on financial risk management, 2) Asset structure influences and significantly affects the value of the firm, 3) Capital structure influences and significantly affects financial risk management, 4) Capital structure has no effect and is insignificant on the value of the firm, 5) Macroeconomic influences and significantly on financial risk management, 6) Macroeconomics influential and significant on the value of the firm, 7) Financial risk management influences and significantly on the value of the firm
\end{abstract}

Keywords: Asset Structure, Capital Structure, Macroeconomics, Profitability Performance, Financial Risk Management, Value Of The Firm

\section{INTRODUCTION}

The vision and mission of the Islamic capital market, is to make the Islamic capital market a significant contribution to the national economy, fair and protect the community. The Islamic 
capital market has an important role,that is as a source of funding for companies for business development through the issuance of syari'ah securities, as a means of syari'ah securities for syari'ah capital market investors that are Universal and, can be used by anyone regardless of their particular background, ethnicity, religion and race.

Syari'ah capital market performance is not only determined by internal factors, but also by external factors. The internal factors of the company is fundamental factors that is often used by investors in determining investment decisions. Internal factors, that is liquidity, research (LisaKititikasari, 2001) include the current ratio, quik ratio, net working capital. Research (EristoTengkue, Paulina Van Rate, 2016), Leverage ratios, include debts to total assets, debt to equity ration. Makro Economics, research (Bambang Sudiyanto, 2010) indudes exchange rates and inflation. Investment in the Islamic capital market is an investment that carries a high level of risk. The risk can be classified as diversified risk, that is risk that cannot be eliminated by diversification, while the risk that can be eliminated by diversification is called unsystematic risk and it is verifeied with liquidity risk (financial risk management)

The purpose of this study is to test, analyze and prove 1) means: the effect of asset structure on financial risk management, 2) means: the effect of asset capital structure on the value of the firm, 3) means: the effect of capital structure on financial risk management, 4) means: the effect of capital structure on the value of the fiem , 5) means: the influence of macroeconomic on financial risk management, 6) means: the influence of macroeconomic on the value of the firm, 7) means: the effect of financial risk management on the value of the firm.

\section{BASIC THEORY}

The understanding of financial ratio analysis or known as financial risk management is as a tool to compare the numbers contained in financial statements and also to see or know the financial position of a company and assess the performance of company management. Types of financial risk according to Irham Fahmi ( 2012: 59), classified into 6 groups namely 1) liquidity ratio: the company's ability to meet short-term obligations in a timely manner. 2) leverage ratio: the company's ability to measure how much the company's activities are financed with debt. 3) activity ratio: the ratio that illustrates the extent to which a company uses its resourcest has to support the company's activities. 4_ provitability ratio measures the effectiveness of overall management as indicated by the size of the level of profits obtained in relation to sales and investment. 5) growth ratio: measures how the company's ability to maintain its position in the industry and in economic development in general, the market value ratio illustrates the conditions that occurred in the market

Weston and Brigham (2005: 175), asset structure is a balance or comparison between fixed assets and total assets. Meanwhile according to Syamsudin (2007: 9) the structure of assets is determining how much allocation and for each component of assets, both in current assets and in fixed assets according to Kasmir (2013: 134) understanding current assets are company assets that can be used as money in time short (maximum one year), the components of current assets include cash, banks, securities, receivables, inventories, prepaid expenses, accrued income, loans and other current assets. Indonesian Accounting Association (IAI) (2012: 16: 1) states that fixed assets are tangible assets that are owned to be provided in the production or supply of goods or services to be bounced off to another party, for administrative purposes and are expected to be used for more than one period.

Capital structure is the composition of ordinary shares, preferred shares and various retained earnings and long-term debt that is maintained by the business entity in funding the assets of 
Irham Fahmi (2012: 106). Capital structure can change because of policies and actions taken by companies related to funding, as for the factors that affect: 1) asset structure, 2) company size, 3) profitability, 4) company growth, 5) business risk, 6) corporate control , 7) capital costs, 8) company stability, 9) statutory regulations, 10) stakeholder preferences.

Macro economic theory states that the movement of inflation is a fundamental factor, a macro of healthy macroeconomic indicators, because the price of goods in general increases. The second macro fundamental indicator of interest rates of macroeconomic conditions is the interest rate, the interest rate is used as a measure of income obtained by the owner of capital. The exchange rate is the price or value of the local currency against foreign currencies and economic growth illustrates that people's lives have an increase in income, so it has the potential to increase or decrease investment in the real sector and will have an impact on the performance of the Islamic capital market. Asifia Murni (2006: 196)

Unexpected event can result in losses, financial risk management has the potential to affect syari'ah an market performance and company value. Based on Bank Indonesia regulation no. 5/8 / PBI / 2003 and amendments no. 11/25 / PBI / 2009, regarding risk management for commercial banks, explains that there are 8 types of risks faced by banks, namely credit risk, liquidity risk, market risk, operational risk, legal risk, reputation risk, compliance risk and strategy risk.

According to Harmono (2011: 87), a company's performance is reflected by the stock price formed by demand and supply which reflects the public's assessment of the company's performance. The value of the company is expected to be used as small as possible by taking into account the amount of capital invested. The value of the company in this study is measured using the indicators of EPS, PER, DPR..

Several previous studies relating to the problem of liquidity, leverage, financial risk management, value of the firm, have been conduated by previous researchers, including R.DewintaNurAnisa, Ratna Wardhani (2014), performance testing, concentration of ownership structure has a positive effect except on the NIM performance, influencing negative Ulfi Pristiana (2019), investment dicision has a significant effect on financial risk management. Setiadharma S and Muslichah Machali (2017), there is a direct influence of asset structure on firm value, I Putu Andre Sucita, I Made Karya Utama (2014), asset structure has no effect on stock prices. Lisa Kartikasari (2001), operating leverage, firm size and profitability significantly influence systematic risk, Isabela Permata Dhani (2017), Bambang Sudiyanto (2010), macroeconomics (inflation, exchange rates, interest rates, economic growth) significantly influence risk company. Oka Aditya, Prima Naomi (2017), together, ERM and control variables consisting of company size leverage, profitability, sales growth and dividend policy have a significant effect on firm value

\section{RESEARCH METHODS}

The population and sample of this study are all companies that registered in the Jakarta Islamic Index as many as 16 companies, the sampling technique is saturated with the 1) criteria companies that registered in the Jakarta Islamic Index during the 2013-2017 period, 2) companies have published annual financial reports during period 2013-2017, 3) companies that provide data related to research variables. The data used are secondary data, sourced from IDX (Indonesia stock exchange), research data analysis techniques using statistics with PLS tools 
The independent variable is an asset structure with indicators of current asset structure, fixed asset structure, and other asset structures. Capital structure with indicators DAR, DER. Macroeconomic indicators with inflation, interest rates, exchange rates. Intervening financial risk management variables with indicators of accounts receivable turnover, asset turnover, revenue turnover. The dependent variable value of the firm with indicators EPS, PER, DPR.

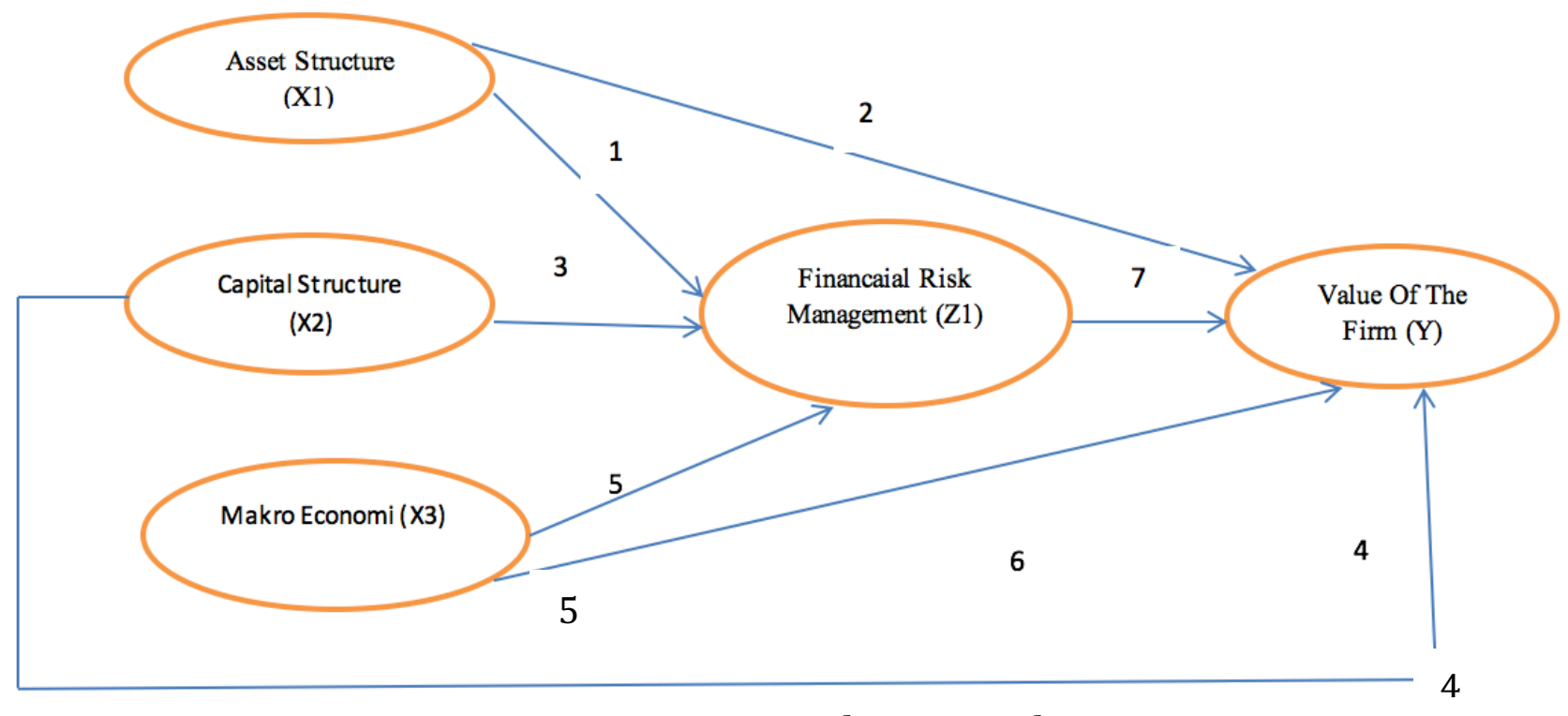

Image Conceptual Framework

RESEARCH RESULTS AND DISCUSSION

The hypotheses in this study are:

\section{The effect of asset structure on financial risk management}

A large asset structure coupled with the smoothess of the asset structure owned by the company will guarantee the company has a consistent value in the future so managers do not want to bear the risk by making decisions using high debt. These results are consistent with research from (Sukmi Amelianty: 2012), stating that total assets have a negative and significant effect on company business risk. (Ni Made Dhyana: 2017), states the structure of assets does not have a significant influence on debt policy. This means that if the asset structure increases, the financial risk management will be small

H1. The asset structure has no effect on financial risk management

\section{The effect of asset structure on the value of the firm}

Asset structure describes the amount of assets that can be guaranteed by the company, when the company makes loans to creditors. Asset structure is the proportion of fixed assets owned by the company. Companies with stable finance have a high investment value in terms of fixed assets. When assets are used optimally, it will increase the company's retrun and ultimately affect the value of the company (Eristo: 2016), stating partially shows the structure of assets, company growth does not significantly influence profit optimization. These results are consistent with research from (Setiadharman.S: 2017) which states that there is a direct influence of asset structure on firm value. (Hata, Tri Ratnawati, Sunu: 2015) states that asset structure, capital structure, market risk have a significant effect on firm value. This means that if the asset structure increases, the value of the firm also increases

H2. The asset structure influences the value of the firm 


\section{The effect of capital structure on financial risk management}

The capital structure is very influential on financial risk management, the higher the business risk of the company, the higher the risk of obtaining funding from external sources. High risk is very difficult to find investors, where investors do not dare to take risks for fear of loss. Companies with high risk tend to use internal funds owned by the company. These results are in accordance with research from (Lisa Kartikasari: 2001) stating that operating leverage, firm size and profitability significantly influence systematic risk. (Arsyil: 2018) states the leverage and size of the company have a significant positive effect on risk management disclosure. This is if the capital structure (company capital is greater than debt capital), then the financial risk structure will have no effect.

H3. Capital structure influences financial risk management

\section{The effect of capital structure on the value of the firm}

Capital structure is influenced by asset structure, cost of capital, asset growth, profitability, company growth rate, business risk, company control, sales stability and statutory regulations. Company value is how the company generates the level of the profit. This result is in accordance with research from (Iin Mutmainah: 2015) which states that the capital structure is projected with leverage and the pro- tected profitability (ROA) has a positive influence on earnings quality. (Isabela: 2017) states capital structure has no effect on firm value. (Hatta, Tri Ratnawati, Sunu: 2015) states that the capital structure significantly influences the value of the company. (Dewa Kadek: 2011) states that capital structure has a positive and significant effect on the value of the company. This is if the high value of the company is expected to have more internal funds so that the company can meet all needs without having to take funds from another company.

H4. Capital structure does not affect the value of the firm

\section{The influence of macro economic influence on financial risk management}

Macro economics is an important factor that must be considered, because this factor is part of the conditions caused by external conditions such as: political stability and security, legal, social, cultural, this factor has a lot of influence on government policies, especially in the problem of the use of external funds. The instability of external factors will cause investment to be more risky and have an impact on reducing company performance. These results are consistent with research from (Bambang Sudiyanto: 2010) stating that the macro economy (inflation, interest rates, exchange rates) has a significant effect on company performance. (Bambang, Cahyani: 2009) stated that inflation had a negative and significant effect on systematic risk. The interest rate has a positive effect on systematic risk. Exchange rates have a negative and significant effect on systematic risk. This is, the higher the risk, the higher the potential profit

H5. Macro economic influence on financial risk management.

\section{The influence of macro economics on the value of the firm}

The interest rate is often used as a measure of income that is earned by the owners of capital, this interest rate is called the interest on savings or investment interest. Likewise, the interest rate is used as a measure of the cost of capital that must be incurred by a company to use funds from capital owners to decline in company performance because the impact of inflation is felt by all companies. So that no single company can avoid the effects of inflation. This condition will affect capital market work. Because many companies cannot operate optimally, as a result the capital market faces high uncertainty and this will affect stock prices. These results are consistent with research from (Ni Made: 2013) stating that macroeconomic factors have no significant effect on firm value. (Nurdina; 2017) stated that DER research and inflation had no effect on PBV. (Muhammad Faizal; 2016) states that the value of the exchange rate, the 
exchange rate, inflation and economic growth directly have a negative effect on retrun stocks. This company is able to increase its profits even though interest rates, high exchange rates cause investors to invest their funds in the form of shares, causing share prices to increase.

H6. Macro economic influences the value of the firm

\section{The influence of financial risk management affects the value of the firm}

Financial risk management in modern portfolio theory can be devided into two types of risk. This type of risk is a systematic risk or known as market risk or general risk (general risk) which is a risk that associated with changes that occur in the market in overall. Unsystematic risk or specific risk (company risk) is a risk that is related to company value. This result is consistent with the research from (Niluh Putuh; 2015) states that business risk has a significant negative effect while the size of the company has a positive effect on firm value. (Oka Aditya; 2017) states that together the size of the company, leverage profitability, sales growth, stock prices have a significant effect on the value of the company. (Bambang Sudiyanto; 2010) states that systematic risk significantly influences company performance. Company performance has a significant effect on firm value. The company is able to increase its profits even though in the rates, inflation and exchange rates increase so that investor confidence does not decrease.

H7. Financial risk management affects the value of the firm

Table 1. Validity of Converting Models (Dropping)

\begin{tabular}{|l|l|c|c|}
\hline \multicolumn{1}{|c|}{ Variabel } & \multicolumn{1}{|c|}{ Indicator } & Value Outer Loading & Description \\
\hline (X1) Asset Structure & (X1.1) Flow Structure & 0,968064 & Valid \\
& (X1.2) Outer Structure & 0,543719 & Valid \\
\hline (X2) Capital Structure & (X2.1) DAR & 0,998335 & Valid \\
& (X2.2) DER & 0,998330 & Valid \\
\hline (X3) Macro Economics & (X3.1) Inflation & 0,942452 & Valid \\
& (X3.2) Interest Rates & 0,925457 & Valid \\
& (X3.3) Exchange Rate & 0,991120 & Valid \\
\hline (Z1) Financial Risk & (Z1.2) Asset Tunover & 1,000000 & Valid \\
Management & & & Valid \\
\hline (Y) Value Of The Firm & (Y1.1) EPS & 0,916905 & Valid \\
& (Y1.3) DPR & 0,908614 & \\
\hline
\end{tabular}

Source: PLS analysis results

Table 2. Variable Descriptive

\begin{tabular}{|c|l|c|c|}
\hline No & \multicolumn{1}{|c|}{ Effect Between } & T- Statistics & Variable Information \\
\hline 1 & (X1) Str Asset $\rightarrow$ Fin Risk Management & 1,051764 & Not significant \\
\hline 2 & (X1) Str Asset $\rightarrow$ Value Of The Firm & 12,522477 & Significant \\
\hline 3 & (X2) Str Modal $\rightarrow$ Fin Ris Management & 6260,609622 & Not significant \\
\hline 4 & (X2) Str Modal $\rightarrow$ Value Of The Firm & 0,4301660 & Significant \\
\hline 5 & $\begin{array}{l}\text { (X3) Macro Economics } \rightarrow \text { Fin Risk } \\
\text { Management }\end{array}$ & 5,463214 & Significant \\
\hline 6 & $\begin{array}{l}\text { (X3) Macro Economics } \rightarrow \text { Value Of The } \\
\text { Firm }\end{array}$ & 3,982465 & Significant \\
\hline 7 & $\begin{array}{l}\text { (Z) Fin Risk Management } \rightarrow \text { Value Of } \\
\text { The Firm }\end{array}$ & 1,962247 & \\
\hline
\end{tabular}

\section{Source: PLS analysis results}

\section{DISCUSSION}

Based on the results of table 2 shows the significant set $\mathrm{t}$-count must be greater than $\mathrm{t}$-table (Ghozali, 2014; 78) say significant 5\% ( $\mathrm{t}$-count $>\mathrm{t}$-table 1.96 is said to be significant) 
1. Asset structure does not have a significant effect on financial risk management, as evidenced by the t-statistic value of $1.051764<1.96$ which means it is not aligned between the asset structure and financial risk management, this is not in line with the theory that the ratio of fixed assets with total assets will affect financial risk management, liquidity theory states the company's ability to meet obligations in the short term, that the company has not managed the asset structure properly.

2. Asset structure has a significant influence on the value of the firm, as evidenced by the tstatistic value of 12.522477> 1.96, which means that between the asset structure and the value of the firm, this study supports the theory that the ratio of fixed assets to total assets affect investor perceptions of increasing company success.

3. Capital structure has a significant influence on financial risk management, as evidenced by the t-statistic value of $6260.609622>1.96$ which means the direction of the capital structure of financial risk management, this study supports the theory that the company's ability in its activities to settle long-term obligations can be fulfilled with the right timeframe.

4. Capital structure does not have a significant influence on the value of the firm, as evidenced by the t-statistic value of $0.430160<1.96$ which means it is not in the same direction between the capital structure and the value of the firm, this study does not support the theory that the company does not able to settle obligations in the long run in a timely manner, this shows that the company's capital structure has not been well managed. The level of success in a company is very high if it is associated with stock prices, if the stock price gets high, it will make the value of the company is also high , vice versa if the stock price gets low, it will make the value of the company also go down.

5. Macro economics has a significant influence on financial risk management, as evidenced by the t-statistic value of 5.463214> 1.96 which means the direction of the capital structure of financial risk management, this study supports the theory that an overall event measured by inflation, interest rates and exchange rates affect financial risk management

6. Macro economics has a significant influence on the value of the firm as evidenced by the t-statistic value of 3.982465> 1.96 which means the direction of macroeconomics towards financial risk management, this study supports the Irving Fisher theory states that the interest rate is influenced by inflation, the government will increase SBI interest rates, causing the profits derived by companies to decrease.

7. Financial risk management has a significant effect on the value of the firm as evidenced by the t-statistic value of $1.962247>1.96$, which means the direction of financial risk management toward the value of the firm. This is a high risk, the profit will be high, and vice versa if the income is low, the risk will also be low and have an impact on the value of the company.

\section{Conclusions}

\section{CONCLUSIONS AND SUGGESTIONS}

1. Asset structure has no influence and no significant effect on financial risk management, for companies that is listed on the Jakarta Islamic Index, from 2013 to 2017

2 Asset structure has significant influence on the value of the firm, in companies that is registered in the Jakarta Islamic Index, from 2013 to 2017.

3 Capital structure influences and significantly affects financial risk management, in companies that is registered in the Jakarta Islamic Index, the period 2013 to 2017

4 The capital structure has no effect and is not significant to the value of the firm, in companies that is registered in the Jakarta Islamic Index, from 2013 to 2017. 
5 Macro economics influences and significantly affects financial risk management, for companies that is listed on the Jakarta Islamic Index, the period 2013 to 2017.

6 Macro economic influences and significantly affects the value of the firm, in companies that is registered in the Jakarta Islamic Index, the period 2013 to 2017.

7 Financial risk management has significant and significant effect on the value of the firm, in companies that is registered listed on the Jakarta Islamic Index, the period 2013 to 2017

\section{Suggestion}

1. Investors are advised to be more careful in choosing companies to invest funds by looking at asset structure, capital structure, macroeconomic, financial risk management, profitability performance, going concern and GCG with the aim of increasing the value of the firm.

2. For companies it is recommended to always increase the value of the company, so that investors continue to invest in the company which in turn will increase stock prices and have a good impact on the value of the company in the eyes of investors.

3. Further researchers are expected to add research variables, different objects such as Islamic banks and longer observation years in order to obtain better results.

\section{References}

Aditya, Oka, and Prima Naomi, 2017, Implementation of Corporate Risk Management and Corporate Value in the Construction and Property Sector, pages 2461 - 1182rn, Journal of Business and Management, vol.7 (2) October 2017

Boediono, 2014, Macro economics, Publisher: BPFE Yogyakarta

Dhani, Isabella Permata, and A.A.Gede Setia Utama, 2017, The Effect of Growth, Capital Structure and Profitability on Company Value. Page 135 - 148, Journal of Airlangga Accounting and Business Research, Vol 2 no 1, 2017

Dwipartha, Ni Made With a, 2013, The Effect of Macroeconomic Factors and Financial Performance on Manufacturing Company Value, IDX, pages 226 -248. Journal of Economics and Business, Faculty of Economics, Udayana University,

Fahmi, Irham, 2012, Analysis of Financial Statements, second edition, publisher: Alfabeta, Bandung

Faisal, Muhammad, 2016, Influence of Rupiah Exchange Rate (Exchange Rate), Inflation and Economic Growth Against Stock Returns on IDX Banking Companies, pages 232-250, Jurnal Valuta, vol.2, no.2, October 2016.

Fred, J, Weston and E.F. Brigham, 2005, Fundamentals of Financial Management, 9th edition, publisher: Erlangga, Jakarta.

Ghozali, Imam, 2014, Structural Equation Modeling, PLS, publisher: Diponegoro University, Semarang.

Herman, Darmawi, 2005, Risk Management, publisher: Bumi Aksra, Jakarta

Munawir.S, 2004, Analysis of Financial Statements, 4th edition, print11, publisher: Liberty, Yogyakarta.

Murni, Asfia, 2006, Macroeconomics, publisher: Jakarta, PT.Refika Aditama

Nasser, Etty M., (2008), The Effect of Ownership Structure and Independent Board of Commissioners on Company Value with Earnings Management and Debt Policy as Intervening Variables, pages 1-27.

Nurdina, 2017, The Effect of Financial and Macroeconomic Ratios on Company Value in Automotive Companies and Its Components Registered on the Indonesia Stock Exchange, pages 17 - 35. Journal of Islamic Economics, vo.9, no.1, December 2017.

BI Regulation No.5 / 8 / PBI / 2003, amendment no. 11/25 / PBI / 2009 risk management

Permatasari, Ika, and Retno Novitasary, 2014, The Effect of GCG Implementation on Capital and Banking Performance in Indonesia: Risk Management as an Intervening Variable, pages 52 - 59. JEKT Journal, vol 7, no.1.

Prayoga, Bangkit, Edo, and Lucia Spica Amelia, 2013, The Effect of Company Ownership Structure and Size on Risk Management Disclosures, pages 1 - 19. Journal of Accounting and Finance, vol. 4 no.1. March 2013 
Rachmat, Firdaus, and Maya Ariyanti, 2009. Commercial Bank Credit Management, issuer: Alfabeta, Bandung.

Rahmiyatun, Fitri, and Kaman Nainggolan, 2016, Effect of Asset Structure, Capital Turnover and Funding on the Profitability of Pharmaceutical Companies, pages 156 - 166. Journal of Sprott, Doaj, Management and Business, vol, 4 no, 2 (2016)

Risdawaty, Eka, Iin Mutmainah, and Subowo, 2015, The Effect of Capital Structure, Company Size, Information Asymmetry and Profitability on Profit Quality. pages 109 - 118, Journal of Accounting Dynamics (JDA) vol.7 no.2, September 2015

Riyanto, Bambang, 2008, Fundamentals of Corporate Expenditures, 5th edition, publisher: BPFE, Yogyakarta. S.Setiadrma, and Machali, 2017, The Effect of Asset Structure and Company Size on Firm Value with Capital Structure as Intervening Variables, pages 232 - 242. Journal, J Bus Fin Aff, 2017, vol, 6 (4): 298.

Saleh, Hatta, and Sunu Priyanwan, and Tri Ratnawati, 2015, Effects of Asset Structure, Capital Structure and Market Risks on Growth, Profitability and Company Values listed on the IDX.Vol 4. Issues pp.471 -501. 